\title{
The effect of product-based and process-based teaching on writing efficiency of Iranian EFL learners
}

Jouzdani, Mani

Islamic Azad University, Isfahan (Khorasgan) Branch, Iran (Mani.jouzdani@yahoo.com)

Biria, Reza

Islamic Azad University, Isfahan (Khorasgan) Branch, Iran (Biria_reza@yahoo.com)

Mohammadi, Majid

University of Isfahan, Iran (m.mohammadi7272@yahoo.com)

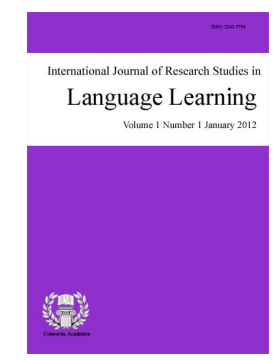

ISSN: 2243-7754 Online ISSN: 2243-7762

OPEN ACCESS

\section{Abstract}

Writing in English has been a major topic of interest for the researchers in the last decade. Learners, who are learning English as a foreign language have always tackled with the problem of writing. There have been many investigations conducted in this regard, all of which proposed various solutions to this problem. In the present study it was endeavored to investigate whether teaching based on product and process writing can affect the performance and efficiency of Iranian EFL learners in writing. In order to achieve this goal, a group of intermediate and teenage learners were instructed based on product and process orientation to writing and the writing assignments in each group were corrected and an inter-rater rating system was used through which the assignments were corrected by two rates, who were experienced EFL teachers, as the last phase of the study a retrospective think-aloud procedure was conducted and the learners provided their opinion on the product and process writing. The results proved that the scores of the writing assignments based on process writing were higher than those of product-writing, therefore it was concluded that process-based teaching of writing had positive effects on improving the writing efficiency of learners.

Keywords: EFL learners; inter-rater; product-writing; process-writing; retrospective think-aloud procedure 


\section{The effect of product-based and process-based teaching on writing efficiency of Iranian EFL learners}

\section{Introduction}

Many studies have been conducted so far on the writing of EFL and ESL students. There have been various factors introduced and believed to affect the writing of the students. Writing in foreign language is a perplexing process for EFL learners especially in intermediate and lower-intermediate level. Also the feedback that the teachers give on the students' writing have pivotal role in determining the success of the learners. Many studies have proved that teaching writing is beneficial for learners. The evidences for this claim will be grounded through providing instances of the investigations conducted in this regard.

Salima (2012) conducted an investigation on how to eliminate the errors of EFL learners in writing. Salima (2012) believes that one of the main sources of difficulty for EFL learners is writing in foreign language. The question which was supposed to be answered in this study was "why EFL students make so many mistakes in writing?" In this study teachers and students were tested. The students were observed and their writings were analyzed and the 25 teachers were given questionnaire to check their feedback on the results. The results of the study suggested that the learners didn't have enough background knowledge in English and they did not consider English as a serious skill. The researcher suggested that in order to help learners improve their writing skills, it is better to advise them to review the words they have already studied and learned and learn new words as well. The results of this investigation are in line with the present investigation in the sense that the researcher has endeavored to find solutions to the issues in writing among EFL learners.

Golestan and Alhossaini (2013) conducted a research on the efficacy of explicit teaching and consciousness-raising in IELTS writing. To this aim, 45 IELTS candidates were assigned to experimental and control groups. The explicit groups were taught writing explicitly while the consciousness-raising group were asked to determine why they had selected particular grammatical structures. The results of the study proved that consciousness-raising had more effect on improving writing skills of the candidates. In this study the role of teaching writing explicitly has been delineated and consciousness-raising has become the point of interest in teaching writing. While, Mourssi (2013) claimed that teaching writing is a complex process which involves varieties in content, sentence structure, vocabulary, punctuation, spelling and letter formation. Therefore, Mourssi (2013) mentioned that the method used in teaching writing may vary from one individual to another. In this paper, the focus is on innovative method of teaching writing which is somehow complementary to product/guided and process writing. This innovative method is mainly based on metalinguistic and error/contrastive analysis as well as communicative interaction and negotiating the meaning.

Martin and Provost (2014) studied the effect of teaching students the ability to discriminate between good and poor writing on their performance and efficiency in writing. In order to achieve this goal, 156 students from the University of Tasmania were selected and were given two writing samples to judge and choose the more appropriate one. After the judgment they were asked to complete a piece of written work which was later on assessed, as mentioned in Martin and Provost (2014), through Six-subscales Quality Scale (SSQS) (Phadtare et al., 2009). The process was repeated a few weeks afterwards and a factor analysis was performed to determine which factors had most effect on the writing of the learners. The results of the factor analysis revealed that two factors which could be categorized as "surface" and "deep" had the most significant effect. The final results of the post-test revealed that teaching learners to discriminate between good and bad writing along with the knowledge of appropriate writing skills had positive effect on improving learners' writing skills.

Amirsheibani and Iraji (2014) conducted an investigation on the effect of using CALL (Computer Assisted Language Learning) on teaching writing. To this end 61 male and 40 female language teachers participated in the 
study. A questionnaire was given to the teachers which consisted of two parts, part one consisted of the personal information and part two was related to the feeling of the teachers about using computer. After the results were analyzed via SPSS it was proved that teachers had a tendency toward teaching writing through computer. The empirical findings of this study focused on the teaching of writing from the computerized point of interest.

Kazemi, Katiraei, and Rasekh (2014) investigated the effect of using lexical bundles on the writings of the learners. 40 bundles were selected and taught to M.A students of TEFL and also they were asked to write two sets of draft, one before the instruction and one after the instruction. The writings were collected and a questionnaire was given to learners in order to collect their ideas on the process. The results of the study showed that the effect of the bundles on improvement of learners' writing was significant. Based on the findings of this study it can be inferred that teaching specific aspects of writing to learners can have significant effect on the improvement of their writing skill. This is in line with the aim of the present investigation in the sense that teaching process and product writing to learners might have effects on improving their writing skills. In addition, Fang (2014) conducted a research on teaching Russian to Chinese students. The focal point of this investigation was on the errors that Chinese learners had in writing in Russian language. The linguistic knowledge and general language efficiency of the Chinese learners were believed to have significant effect on their improvement in writing in Russian. The results of this study showed more culturally specific aspects of language to be crucial in improving the writing of the learners. It is worth investigating the effect of teaching writing and its effect on the improvement of learners in writing beside culturally specified aspects of language.

Klimova (2015) studied the effect of teaching abstract writing on the improvement of academic writing of the students when they endeavor to write abstracts in English. Klimova (2015) believed that teaching academic students how to write abstracts would improve their efficiency in writing research paper abstracts. To this aim, the students were taught through various methods and strategies and also the researcher provided a video containing the guidelines to writing academic abstracts. Klimova (2015) concluded that teaching academic writing was not an easy process to undergo, the learners were believed to have to acquire profound knowledge of general English knowledge, therefore, the learners were needed to improve their general English in advance in order to be prepared for writing an academic and acceptable abstract.

Ketabi (2015) investigated the effects of assessing writing through various methods among Iranian EFL teachers on the improvement of writing. The instrument used in this study was a questionnaire, the data gathered after the questionnaires were scored and analyzed, showed that the most common methods used by the teachers were writing essays and dictation. Portfolios were among the least used methods based on the findings. Assessing writing through different methods proved to be useful in this investigation. While, Mosmery and barzegar (2015) studied the effects of peer, self and teacher assessment on Iranian's EFL writing at three different task level difficulties. For the purpose of this study, 81 learners out of 117 were selected and afterwards they were grouped in three, peer, teacher and self-assessment group. After the training they were asked to write in three different levels of difficulty (easy, medium, complex). The results showed that self-assessment was the most beneficial and preferable method used over three groups.

The research studies conducted on teaching writing have introduced various factors than can affect the efficiency of writing among EFL learners. But a few evidences have been provided regarding the effects of product and process based teaching of writing on EFL learners' writing skills. Therefore, it is worth investigating the effects of these two specific processes on the improvement of writing abilities of EFL learners.

There were two research questions posed in the beginning of this study:

$>\quad$ Will the learners get different scores on product and process writing?

Will process-based teaching have improving effect on the score of writing?

Based on the questions posed the following hypotheses were formed: 
Jouzdani, M., Biria, R., \& Mohammadi, M.

$>\quad$ The learners' scores will not differ in product and process writing.

$>$ Process-based teaching won't improve learners' scores in writing.

\section{Method}

Design - The present study followed a mixed method design with triangulation which included teaching through product and process based writing followed by a retrospective think-aloud procedure.

Participants - The participants selected for the purpose of this study were 30 male intermediate EFL students who were selected form an institute in Isfahan, Iran. All of the participants were placed to intermediate level using Oxford Placement Test prior to the course. The course instructor was a 25 years old male EFL teacher who had nearly 8 years of experience in teaching English as foreign language.

Instruments - The instruments used for the purpose of this study were two topics given to the learners to write about and a retrospective think-aloud procedure. The topics were related to product-oriented teaching and process-oriented teaching independently and the retrospective think aloud procedure was conducted for both product phase and the process phase of teaching.

Inter-rater reliability - The results of an inter-rater scoring procedure cannot be reliable by itself. It is of utmost importance to carry out a reliability test in order to ascertain that there is an agreement between the scores of the two raters otherwise the findings will be subjective and unreliable. Cohan's kappa test of estimating reliability was used in the present investigation to check the agreement of the scores given to the learners by the two raters.

Procedures - The teacher was asked to teach through two types of writing, namely, product and process writing during a term of 3 months period. The half of the term was spent on process writing and the other half was spent on product writing. At the end of each period, the teacher was asked to give a topic to the learners to write, in the first period the students were asked to write product writing and in the second period they were asked to write process writing. After each writing phase, the students were randomly selected and were interviewed to check their reflection on the teaching process related to product and process based teaching. The scores of the learners in both product and process based writing were then calculated through inter-rater procedure which involved two teachers of the same experience. At the end, the mean score of both groups were calculated with a paired t-test using SPSS 23.0.

\section{Results and Discussion}

When the teaching based on product and process writing was finished, at the end of each teaching period a writing topic was given to the learners and they were scored through an inter-rater system by two raters. The mean scores of two raters were calculated for both product and process writing samples of the learners. The mean scores of product and process writing samples were compared using paired t-test. The results of the comparison between the mean scores of product and process writing are provided in Table 1.

\subsection{Paired t-test results}

\section{Table 1}

The results of paired t-test

\begin{tabular}{|c|c|c|c|c|c|c|c|}
\hline Types of teaching writing & Mean & $\begin{array}{l}\text { Std. } \\
\text { Deviation }\end{array}$ & $\begin{array}{c}\text { Std.Error } \\
\text { Mean }\end{array}$ & $\begin{array}{c}95 \% \\
\text { Confidence } \\
\text { Interval } \\
\text { Dif. }\end{array}$ & $\mathrm{t}$ & df & $\begin{array}{c}\text { Sig, } \\
\text { (2-tailed) }\end{array}$ \\
\hline Product-Process & -2.62500 & 2.01396 & .36770 & $\begin{array}{l}-3.37702 \\
-1.87298\end{array}$ & -7.139 & 29 & .000 \\
\hline
\end{tabular}


Based on Table 1, the difference between the mean scores of product and process writing is negative. It suggests that the mean score in process writing is higher than product writing, therefore, it can be concluded that learners achieved higher scores in process writing compared to product writing. Also the 95\% confidence interval is negative which suggests that the scores of the learners in process writing were higher than their product writing scores. The significance of the results is 0 which means that the difference between product and process scores is statistically significant.

\subsection{Cohen's kappa inter-rater reliability}

In order for the results to be reliable, an inter-rater reliability test was conducted. This reliability test was conducted based on Cohen's kappa. The lowest score given by the raters was 12 out of 20, therefore, the scores were grouped into 4 groups (i.e. score $\mathrm{A}=18-20, \mathrm{~B}=16-18, \mathrm{C}=14-16, \mathrm{D}=12-14$ ). In order to perform Cohen's kappa inter-rater reliability test, these groups were used in SPSS program and the reliability was estimated. The results of the Cohen's kappa test are presented in Table 2.

\section{Table 2}

The results of Cohan's kappa inter-rater reliability test

\begin{tabular}{lcccc}
\hline & Value & $\begin{array}{c}\text { Asymp. Standard } \\
\text { Error }\end{array}$ & Approx. $T$ & $\begin{array}{c}\text { Approx. } \\
\text { Significance }\end{array}$ \\
\hline Kappa Measure of Agreement & .955 & .045 & 8.923 & .000 \\
\hline
\end{tabular}

Based on Table 2, it is concluded that the scores given to students' process and product writing by rater 1 and rater 2 have significant agreement (.955). Cohen's kappa value, which is .955 , shows that there is an agreement between the scores given to the writings by rater 1 and rater 2 . Therefore, it can be concluded that the results were reliable.

\section{Findings}

Based on the statistics, it can be concluded that the first hypothesis formed in the beginning of this study is rejected. The learners' scores varied significantly across product and process writing. The second hypothesis can also be rejected since the learners, based on Table 1, scored higher in process writing compared to product writing. The results of this study showed that process and product based teaching of writing had different effects on the overall performance of the learners regarding their writing scores. The statistics proved that process-based teaching of writing had positive and beneficial effect on improving learners' writing score. Product based teaching was observed to have little effect on learners' writing score. Also the reliability of the results were accounted for and tested through Cohen's kappa inter-rater reliability test and they were proved to be reliable.

\subsection{Pedagogical Implications}

Based on the findings of this study, product-based and process-based teaching of writing have different effects on the writing improvement of the learners. The results of this study suggest that it is advisable that EFL teachers focus on process-based teaching of writing. Teachers have the chance to focus on the process writing in order to improve the scores and the efficiency of the learners through teaching them the process of writing and different steps they have to undergo for a perfect or at least nearly perfect final draft to be achieved. Learners will benefit more from process writing and their writing skills will be improved through the process-based teaching program.

\section{References}

Amirsheibani, M., \& Iraji, M. (2014). CALL and teaching writing: Language teachers' attitude. An Iranian 
Jouzdani, M., Biria, R., \& Mohammadi, M.

survey. Procedia, 258-266.

Fang, Y. (2014). Teaching Russian language writing to Chinese students. Procedia, 292-296. http://dx.doi.org/10.1016/j.sbspro.2014.10.154

Golestan, A. A., \& Alhossaini, M. N. (2013). Efficacy of explicit teaching and consciousness-raising in IELTS writing. Procedia, 853-858.

Kazemi, M., Katiraei, S., \& Rasekh, A. E. (2014). The impact of teaching lexical bundles on improving Iranian EFL students' writing skill. Procedia, 864-869. http://dx.doi.org/10.1016/j.sbspro.2014.03.493

Ketabi, S. (2015). Different methods of assessing writing among EFL teachers in Iran. International Journal of Research Studies in Language Learning, 3-15.

Klimova, B. F. (2015). Teaching Abstract Writing Effectively. Procedia, 908-912.

Martin, F. H., \& Provost, S. C. (2014). Teaching students to discriminate between good and poor writing. Procedia, 205-209. http://dx.doi.org/10.1016/j.sbspro.2014.05.036

Mosmery, P., \& Barzegar, R. (2015). The effects of using, self and teacher-assessment on Iranian EFL learners' writing ability at three levels of task complexity. International Journal of Research Studies in Language Learning, 15-27. http://dx.doi.org/10.5861/ijrsll.2015.928

Mourssi, A. (2013). Theoretical and practical linguistic shifting from product/guided writing to process writing and recently to the innovated writing process approach in teaching writing for second/foreign language learners. International Journal of Academic Research in Business and Social Sciences, 2222-6990.

Salima, R. (2012). Measure of eliminating EFL students' errors in writing. Procedia, 318-327. http://dx.doi.org/10.1016/j.sbspro.2012.11.416 